\title{
吾國産婦人科器械の變遷に就て
}

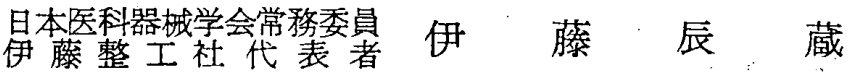

\author{
A Short History of Gynecological and Obstetric
}

Instruments and Equipments in Japan

\section{Tatsuzo Ito}

Proprietor, Ito Seikosha; Standing Committee, JMIA.

明治20年代迄は，専ら外科の一分科として扱はれて いたが各医学校に於て，緒方，池田，足立，捠田，山 田，高山諸先生により 欧州医学の教授を開始せら れ，他面器械類は輸入品を其のま〉使はれるのみの状 態に過ぎかかたか，明治30年代初期に東京及京都帝 国大学に産婦人科教室が新設されてから，主として独 乙に留学せられた先生方が帰朝の都度新器械を紹介せ られ，臨床的に使用の結果，欧州人之の体格の相違に より其の衤使用不可能なものああるので，それぞれ本 邦人に適合する椂, 型, 大さ, 曲り, 太さ等を工夫或 は改良せられ，当時に於ける器用な職工を指導して現 在の様な形態になつたわけである。

新器械の改良工夫に当つては, 直接手術中の見学を 希ひ或は職人を帯同して其の使用する部所の要領を 会得せしめ，先生方の意見に基き，作る者は工作上 の条件を考えて完成に萬進した次第である.

今日に於てす吾々は大なり小なり此の様な苦心をし て居るおけである.

品名に就ては原名其の盡（ネーゲル氏座科鎙子，クス コ一氏胵鏡等）の改良品と，木下式，高山式；吾妻式 桜井式とか日本名のむるものは上記の様な苦心を重ね て完成したもので, 品一ッ一ツに改良の要点があるわ けである。

作る者は右要点を頭に入れて仕上げ，販志する者は 右要領に適合した品を先生方に供給する責任があり ます。

各品に対する要点は小生菲才乍ら四十年の経験と 諸先生方御指導による記憶をるととして発表いた す考です。

\section{[堙、鏡 類]}

明治中期クスコー氏三升が最初で，輸入品の中型を太 として其の下を造つたもので日本橋松本器械店, 本鄉 万木器㑘店, 浅草遠州屋等が最初に取圾つた様です。 明治末期になつて柄の折込式クスコー、トレラート式 等か現はれ，大正中期に大阪の藤村元張先生により藤 村式が考案され, 開業医家の簡単な手術用として重宝
がられたもので, 昭和初期桜井功先生考案の桜井式が 出来てからは，压倒的に普及し特に終戦後の需要は増 大してまます。

最近東大小林隆先生改良による，スライド式と称する ものは一部に好評を得てるる。

単㚏胵鏡としてはクリステル氏，シモン氏，ドイヤン 氏等が最初で，明治30年代柳西蔵先生の改良によるク リステル氏の柄を中空とした通水式が出来てからは一 般に用いられ，同時期高山式，木下式通水が出来てる る.楖式の柄の付根から直角に柄を付计替えた，長さ の短い物は鳥越淡蔵先生考案による卧床用に便利なる。 のである。大正末期下谷に開業して居られる平山鋼三 先生の考案した患者の完に㣣さ板に聯結して使用する 平山式固定胵鏡と言ふのがあつた。クスコ一式のネッ 止を䥀状の歯のついた桿状で自働式に止る様にした土 橋要馬先生の考案品もおつた．上下二弁で鉗子状柄が 横から開閉する様にした物に，飯島式，池田式などが あつたが，何れる一部の人の利用に止つた。

手術用胵鏡としては明治中期翰入された。マルチン 氏，ドイヤン氏，アゥハルド氏等があり，其の改良品 として高山式，木下式が現はれ昭和になつて重りのつ いた安藤式，矢田式，明城式等が出来ている.

\section{〔胎盤鉗子，流産鉗子〕}

明治30年代高山尙平先生により紹介された。高山式 (DIC M 1137) 及此の変形が明治, 大正, 昭和の初期 迄多くの人に利用され，一部の人にヒルスト氏（DIC M 1182)４ンデ氏（DIC M 1126）が使用された. 大 正末期小鷹利三郎先生が考案せられた小鷹式と称する 肉細の釷子が出現した。独特の触感が認められて漸時 愛用者が増し，終戦後は需要の70\%は小覻式又は之の 変形に集注される様になつた。

吾妻式は吾妻勝剛先生の考案したもので, ゼンゲル式 は塚原伊勢松先生が大正十三年渡欧後紹介せられたも のである。

終戦後太田典礼先生により太田式が亦筆者が試作した US 式と称与肉細の物があり，共に利用により効果の 
大であることを実証されて居る。

\section{[子宮䫫管㵠張器]}

ヘガール氏式が最初輸入された様で，原型は先端が微

㮩でパイブの基の方は斜切つた様なるのであつたの を吾妻先生か現在の栚な把手を付けて番号順に束ねる 様に柄に穴をあけ棒で組合せたるので，眀治30年代の 作である. 同時代シュロイデル氏式が荷され，専ら 東大に於て使用せられた関係上別名大学式へガールな どと称されてるる. 最初吾妻式は十五本を一組とし， シュロイデル式は十二本を一組となして居たが，大正 時代より段々太い物を使用する様になり，現在は三十 号迄先年工業標準規格として寸法，太さ等を規定され ている.

大正中期大阪の藤村元張先生により，吾妻式とシュロ イデル式の中間の長さで一号より三十号迄造られたこ とがあつた．同時代にショョーリー氏と称し差込式とな つた十本一組のすのが出来たが番号が一ッ扣きで不便 なので奇数, 偶数のものを組入れて拾本二組として, 木下式往診用と称して一時相当好評を得たすのであ る.

同じく木下式伜入扗張器 (DIC M 146) と言ふ20本 1 組にしたるのがある．柄が二本で交互に差し替えて使 用するのが面到なのか普及しなかつた。明治時代輸入 されたものでホホッシー氏，ワルへル氏，クナップ 氏、ディラタトールがあるが現今あまり使用されてい ない。

昭和九年平沢益吉先生により紹介されたメトラノイク テルは戦啳其の効果を認められたのか需要が漸増して いる.

上記を真似て弾力を弱くしたものに，メタルラミナリ ヤと称するるのが戦後出て来た。.ラミナリヤの代用に 試用されて其の効果の確実さを認められ愛用者が増加 してみる.

\section{[子宮把持鉗子〕}

明治中期より輸入された，マルチン氏単鈎，ミ゙ェン゙ー 氏双鈎が使用されて居るが大正十三年塚原伊勢松先生 が考案せられた塚原式胵部鉗子と称するものが前記二 品の率引により切れたり，出血したりする欠点がない ので賞用されている，最近水野重光先生により単双鈎 鉗子と称して先端一方が単鈎と双鈎になつたるので朣 部の小さい者などに便利であり，率引中はづれる㴅い がないとの事である.

キュストネル氏を原型として其後, 吾妻式, 樋口式, 明城式等があり，サマー氏起整叙子，ゼゴン氏二，三 爪钩, ミオーム, 四爪鈎等, 皆明治末期より大正初期 に入荷紹介されたすのである.
子宮全摘用としてウェルトハイム氏型, 東大式, 岡林 式, 安藤式, 岩田式等があり, 第曲, 長さ, 太さなど 各々特徵が定められ需要は各人の好による。

\section{〔剪 刀 類〕}

明治中期より通常外科用の長さ $14 \mathrm{~cm}$ のものと, 婦人 科用として, シムス氏式と称し反直型二種で長さは $18 ， 20,22 ， 24, \mathrm{~cm}$ の物があわ部の 形状に三通りあ る. 最近八木式子宮鼍手術用と称し内細の軽块なるの と岩田式全摘用の特別強篎のものがある. 昭和初期佃 貞寛先生に上り滕状柄の深部报系剪が考案され, 池田 一男先生によりステッヶル教室で使はれて居る特別の 技糸剪刀が紹介されたことがある。

\section{〔開 腹 鈎〕}

明治中期より専ら外科で使用されているホーツェル氏 二㚏式が使はれていたが明治末期吾妻勝剛先生指導に より三弁式が出来た。

ホーツェル式の関節部をネシ止としなるで、ネーゲル 産科鈤子の如く差込式としたものが木下正中先生改良 によるもので，手術終了後閉鎖時に中央から簡単には つれて便利である。昭和初期洝藤画一先生の考案し た三升状鈎は手術野の多開か自由で取扱に便利で破損 の㧹ひも尠なく一部に賞用されている.

\section{〔銳 鈍匙類〕}

明治, 大正, 昭和にかけて殆んど, ジモン氏，オルス ハウゼン有空鋭匙, ブンム氏鈍题で先端の大さが現在 は数種になつて居る（工業標準規格あり）明治24年頃 川越市に開業されている佐藤俊秀先生の指導により， 匙部の半分をフタしたクルップ题と称する鈍匙を製作 した処多数使用者の実証を得て現在好評である. 明治末期に於ける吾妻式，佐伯式昭和初期に於计る藤 村式等共に一部に使用されている.

\section{〔アレキサンダー手術鈎〕}

通常コッハル氏扁平鈎（大小）の先端桬曲を少し大曲 りとしたもので大正初期熥口繁次先生により特に先巾

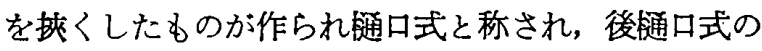
柄部に滑り止を付けたるのが石川式として，又大阪で 両頭に鈎の付いたるのを白井式として，作られ相当の 愛用者があつたが現在は一部の需用に止まつている.

\section{[子宮翻轉器]}

高山先生の賞用せられたるのが最初であるが，昭和八 年沢崎元先生により有空のものが作られ一部使用者に より便利であることを実証されている.

\section{〔子宮畉管通氣器】}

大正初期北大大野精七先生の指導により作られたるの が最初であり使用法も簡便なので現在も汎く使はれて 认る. 
書谷式，秋山式等もあつたが一部に使用されたのみで 終戦後は作られてるない。

\section{〔子宮卵管造影乵注入器〕}

昭和初期より九大式，NTK式，安藤式，堤式等があ るが最も確実に注入管の固定が出来るので NTKが賞 用されて居る.

NTK は昭和五年頃東京警察病院婦人科に於て独乙 文献より探用試作せしもので当時医長の中山栄之 助; 高田徹吾，児玉保三先生の頭字を付したもので ある。

同じ頃九大に於て白木正博先生指導で西島義一先生の 考案により完成したのが九大式である. 操作が簡単で 率引固定の緊張度を感知しつ〉出来るのが便利であ ク，通気術子并世実施出来る特徽がある。

昭和27年東京整察病院和田豊先生の指導により和田式 と称するすのが出来た。

二重導入管の外管先端にゴム帽を被せ子宮內に㨂入し てから膨らませて子宫內口を栓塞固定するすのでミュ ゾー氏鈷子を使用せず好評を得ておる。

\section{[座科聽診器]}

明治中期より木製捍状の物（浜田式後㷁口式と称す） とトラシ・゙氏型が使用せられ，明治30年末期に，トラ ウべ氏型の肉取を薄くして音の反響を良くし捍状の処 を抜いて横差しとして携帯に便利に改良したのが木下 正中先生改良のるのである. 木製捍状のるのは的順次 郎先生により端式と称し，唃口繁次先生の探用せし型 は确口式と称され現在に至つている.

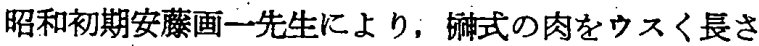
を少し長くした安藤式が作られ一部に利用されてい る.

両耳式は大正初期に榎本六三郎先生により考案され， 後水原式，中林式等があつたが，いつか製作を中止し てしまつた。

\section{〔嫞人科往診器械〕}

明治末期木下正中先生の指導で消毒艋器械入カスト等 金函を鞄に組入たるのがあつたが余り容積が大きく携 行に不便なので..............

大正初期になつ横捠の渡辺義郎先生，小石川の中鴄翼 吉先生の指導によりトラン.ク型横提げ式の容具を製作 したのが (DIC M 822) である.

昭和八年頃東北大学高橋秀吾先生により簡便な往診具 を考案されたが支那事変の影響を受けて製作を中止し てしまつた。

向京都堂阪より高山式と称した物があつたが大体木下 式と大同小異であつた。

\section{〔タンポン藥品台〕}

明治三十年代作られた（DIC M 831）が最初で明治四 十二年東大に外来彰察室が新設されるに当り新に設計 されたのが，今日一般に出廻つている六角型の東大式 である. 此の時代に京大式が次で木下式が出来大正初 期に川添式及（DIC M 819）の型が出来たわけで各々 一長一短がある.

終戦後筆者は前々より計画して居た歯科ニニット式の 綜合的なるのを設計中偶々篠原弘蔵先生の指導を得て 完成したのが $\mathrm{S}$ 式診療ュニットである. 内診室は此の ニニットと內診台と煮沸消畫器があれば他の器具は要 しない.

\section{〔媂人科内診台〕}

明治30年代迄は殆几ど (TIK 第一版) 飞揭載されて居 る木製角形と廻転式のすのが大部分で，同40年䐓より (DIC M 913) 飞(TIK 第一版) にある東大式がポッ ポッ出迴つて来た程度で，大正初期になり東大式改良 型（DIC M 909）と中島式 (DIC R 64) が一般的とな り，第一次欧洲大戦の影響で一般的好況の需用増によ り桑原式と称する簡便な手術併用台が時宜に適して非 常な普及を来し今日に於ても一層の需要を乎んでる る.

其他川添式, 高山式, 安藤式等幾多の改良変形品があ が特殊需要者に限られている.

終戦後弊所より作られたのがS 式 I.S 式等がある.

\section{〔産科鈿子〕}

明治中期紹介せられたネーゲル氏は(DIC M 1066)が 原型であるが一般に普及されて居るのは東大式と称し （DIC M 1056）である. 原形は重量が重く，柄も肉太 で，木下正中先生の指導に上り明治三十七，八年頃改 良したのが東大式である.

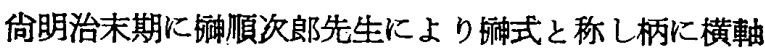
を入れて牽引に便利としたすのがあり，大正中期に白 木正博先生に上り白木式が考案され，それぞれ特徵が あり一部に愛用者があり。キーランド氏鈤子は大正八 年熲輸入され本邦人向に改良されたのが現在のるの である. 早流産用として平山式 (4.5 月月用) 大塚式 （三，四ヶ月用）がある.

\section{[骨 盤 計]}

コラン氏, マルチン氏,ブライスキー氏等は原型の㗐, 目盛を読み易くしたのが東大式，傾斜角度を併せ記録 出来る様にしたのが木下式で, 眀治末期の改良品であ る.

大正初期磐瀬雄一先生によりアールフェルド氏型を作 られ，昭和初期尾島先生により慶大式と称し共に目盛 の細いすのである. 


\section{〔眀管慜挫鉗子〕}

大正八年頃後藤直先生がマドレーネル改良後藤式を作 られたのが最初で次で堤辰郎先生の堤式，柴山幸一先 生のハーゼルホルスト型改良柴山式が出来, 終戦後臆 式手術が盛になるに及び真柄正直先生により特別軽快 なるのが考案され非常な好評を得て居り其の後此の変 型が二三出来て居る.

\section{[郋管把持鉗子]}

昭和初期安井修平先生により試作せられしも一般的に は後藤㨁先生の紹介せし（DIC M 1113）が普及されて 居る.（DIC M1116）の型は伏島興雄先生の賞用にな るもので先端にゴムを被せ卵管の損傷を防ぎ利用価值 のあるものである.

\section{〔妞管 (咽頭) カテーテル〕}

明治末期中島埪吉先生考案が最初で大正初期佐野起次 郎先生の佐野式; 大正中期に佐久間兼信先生の佐久間 式, 次で佃貞寛先生の佃式である. 現在は佐久間式, 佐野式，中島式のみである.

\section{〔分 婏 台〕}

明治末期吾妻勝剛先生の指導により作られたるのが最 初で，大正中期アジマ式の足部が引込式にしたのが， 中山栄之助先生考案のるのでせまい部屋など場所を取 らず便利である.

中山式に腰上装置をしたのが改良中山式 (DIC M 1575）で，次で慶大式，セイロカ式等が出来た.

昭和初期日赤本社病院柴野昇先生の考案々沢崎元先生 の指導により肩受, 足受, 消毒盆架附属した目赤型が 出来た：しかし現在に於ても最す需要の多いのは吾妻 式である.

終戦後改良中山式の足部を引出してから，水平とした 箖原式と，エム，コロナが出来て居る.

\section{〔新産兒保温器〕}

明治卅年代東大婦人科涪設備された全部鉄板製二重壁 の內面フェルト張りで，鉄骨硝子張りの蓋を被せ，保 温は下部抽出に炭団を入れた原始的なものが最初であ る.

大正五年頃安価で一般向の物をと考えて作られたのが 筆者考案の電球式保温器 (DIC M 1654) である. 間 むなく佐久間式と日赤座院型とが現はれ，大正から昭 和の初期迄殆んど此の三種が使はれていた。昭和五年 頃京都堂阪から高級なるのが出たが普及されなから た.

余り高級精巧なるのは新しい內は良く使はれるが一度 故障すると其の儘になる様である．段々と良質な電熱 線と温度自働調節器が出廻つて来たので設計を改良し たのが S式嬰児保温器である.
終戦後エム、コロナ.フトム式等精密高級品がある.

（註） 精密高級品は概枋米国クリーブランド市ゴル ドン，アームストロンク会社製インキュベーター をモデルにしたるのである。

\section{〔産婆携帯具〕}

明治三十六，七年頃に京都に於て高山式東京に於て木 下式と称し, 現在 (DIC M 1723) 型に便器. 手洗盤 等を組入て鞄入とした大きな容積のものであつた。大 正末期から小烟式，佐久間式，横提式等が発売された が一般的に普及されて居るのは（DIC M 1723）型で ある。

\section{〔手 術台〕}

明治三十一年緒方正清, 高山正平, 両先生により手術 位置に於て高盤高位の優れて居ることが提唱せられ， 此の時代に高山式が出来たのが婦人科手術台の最初の 様である.

眀治三十六，七年頃木下正中先生により木下式が出来 次で明治四十一年独乙からハーン万能手術台が後藤風 雲堂に上り輸入され，翌42年筆者先代が本所勝倉製作 所に摸造を命じ，東大婦人科に設置されたのがハーン 手術台の婦人科手術に利用された最初である.

大正初期中島襄吉先生の中島式, 大正末期の川添式, 昭和初期に安藤式 (現在の慶大式) 等が出来た. 此の 外大正初期に出来大桑原式か取扱簡便で価格も安く, 一般に普及されてるる.

\section{〔蒸汽消毒器〕}

明治二十二年頃大阪緒方先生が独乙より輸入せられ乾 蜗装置付の物が最初で, 其の後京都堂阪, 東京松本, 万木，風雲堂等で摸造せられ，大正，昭和々年々改良 エ夫せられ今日の様な完全なものが出来るよろになつ たわけである.

\section{〔熱氣浴器〕}

明治三十九年京大高山倘平先生により紹介せられたの が, 最初のもので, 炭火, アルコールランプ. ガス灯 の熱を被匣の一側から金属円筒により誘導したるの で，大正初期にカーボン電球で，次に電熱ヒーターを 利用するようになつてからは温度調節も可能になり， 現在に至つておる. ヂフテルミー超短波治㞠機等の出 現により現状では余り使はれてるない。

\section{〔熱性洗㣠器〕}

大正初期横山源十郎先生考案 (DIC M 675) のものが 最初で，垂井駿先生の垂井式，昭和初期後藤直先生に より推奨せられた後藤式，大阪に於て広瀬豊一先生の 厷瀬式がある.今日に於ても需用のあるのは横山式文 である。 


\section{〔膀睄洗涂カテーテル〕}

明治三十年代東大千葉先生により稆介された千葉式が 最初で，大正初期蔛口式，昭和初期安藤式；久慈式等 がある。

昭和二十七年山形の横山憲更先生により特殊の洗溁装 置が考案され一部に好評を受けている.

\section{〔持 針 器〕}

明治中期外科手術より転用されだ、マッチュー氏式の 長さを長くしたるのと，ローゼル氏型が専ら使用され ている.

大正初期㷁口繁次郎先生により，へガール氏型が深部 用有利なるを推奖せられ，爾来相当の愛用者があり， 昭和初期に眀城弥三吉先生のマッチューE改良型が出 来て居る.

\section{[電来液體昅引器]}

大正十一, 二年頃市河思誠堂で米国ソーレンセン会社 製の吸引器を輸入したのが最初で，東大に於ても初期 は之を使用して居た。

国座品としては明城弥三吉先生が指導せられて, 東北 大工学部理学部の協力により完成した明城吸引器が最 初である. 後高橋安太郎商店より文献を添付して宣伝 せられ良心的なすのであつた．終戦後各メーカーに於 て強力な吸引器が各種出廻つて居るが, 肝要の吸引嘴 管に於て明城式の様な独創的なるのが現はれてみない
【其の他]

品名 冷却臆”鏡 子宮 洗 滌 カテーテル 㜔式穿剌针

锥管粘液吸除器 卵管焼 枃器 畉管移植穿孔器 卵管通水器 手術用スパーテル 帝王切開分婏管 万 $\overline{7}$ 二 。 トラクトール

コルポ率弓表置

コルポ率引固定器

庆汎子宮全摘要具

後 記 考案又は改良者 年 次 森永友頋先生 明治40年 大石貞夫" 大正初期 横山惠史 .11 大正14年頃 ＂I" " " 勝矢 : $" 11$ 昭和 5 年頃 " " " " " 八木日出夫 " " " 明城弥三吉 "

" " " "

張“房 雄”昭和 6 年頃. 鉐瀬雄一”'大正 8 年頃 柴山幸一”，昭和初期 岩田正道昭和22年 以上

以上明治から昭和現在に到る吾国産婦人科器械の概略 を記述した訳ですが，関東大震災，今時戦災と二回に 亘る被災のため，前々より折にふれ記録しておいた原 稿を焼失して仕舞つたので，記憶を想ひ浮べつ」列記 した次第で甚だ雑駁な点や，年次の多少誤つた所は御 諒承を希い，御気付の点は，御教示を賜り，将来訂正 の資料に致したいと思います。（昭和 28.8)
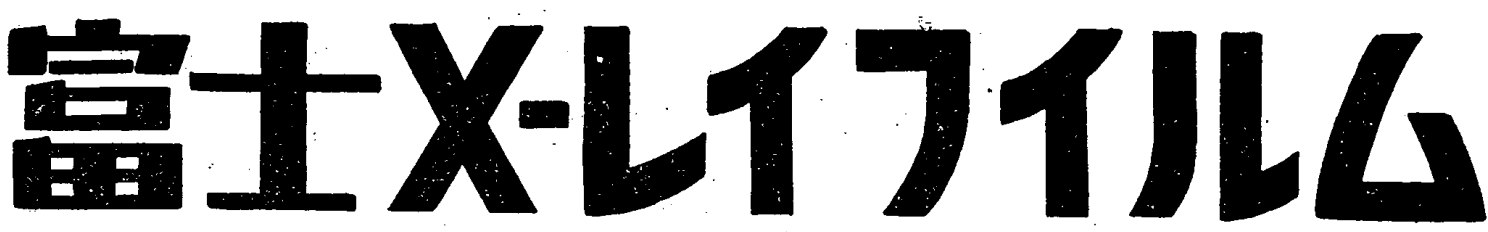

“富士 X一レイフイルム”は増感紙感度に重点を置いて製造 されていますから胸部撮影に最高の性能を発揮します

“レンドール”（富士 X一レイフイルム現像劑）

使用液 : $2.000 \mathrm{c}$. c. 用

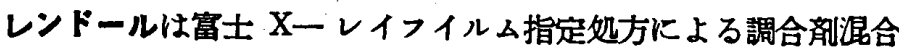
㓮で主剤補助剤とも最高 純度のるのが使用してあります。従つ て現像液の持ちはよく理想的な調子に仕上る上，一々調合する 手数を必要とせずスビーデイに仕事がはかどるので好評です。

“フシフイックス”（富士酸性硬膜定着劑）

使用液 : $4.000 \mathrm{c}$. c.

フジフイックスる亦富士の純䊉 菜品を組合せて造つた酸性 硬膜 定着昘です。各菜品の純度が高いので夜山容易に污染せず短時 間で完全に定着 効果を挙げます。仕事のスピーデイに運ぶこと は富士の他の混合剤と同様です。

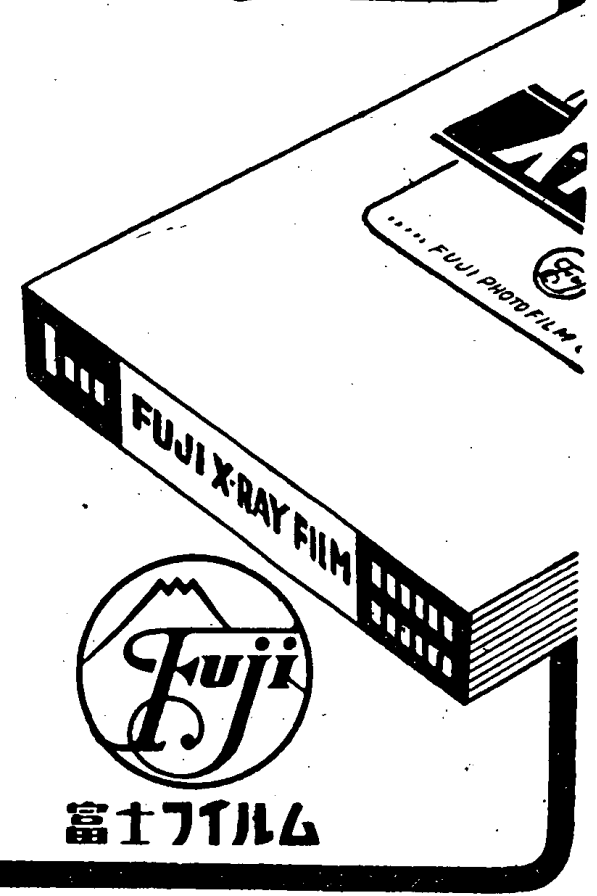

